\title{
Review
}

Respiration 2011;81:253-261

DOI: $\underline{10.1159 / 000322011}$
Received: July 29, 2010

Accepted after revision: October 6, 2010

Published online: November 30, 2010

\section{The Effects of Antiangiogenic Compound SU5416 in a Rat Model of Pulmonary Arterial Hypertension}

\author{
Seiichiro Sakao Koichiro Tatsumi \\ Department of Respirology (B2), Graduate School of Medicine, Chiba University, Chiba, Japan
}

\section{Key Words}

SU5416 - Vascular endothelial growth factor •

Endothelial cells · Pulmonary arterial hypertension

\begin{abstract}
Several lines of evidence indicate that vascular endothelial growth factor (VEGF) plays a prosurvival and antiapoptotic role in endothelial cells. SU5416 is the first VEGF receptor 2 inhibitor to enter clinical development for cancer therapy. A phase I/II study of SU5416 has been completed, and the results show that SU5416 is well tolerated in patients with terminal cancers. It has been shown that VEGF receptor blockade using SU5416 combined with chronic hypoxia results in severe angioproliferative pulmonary hypertension (PAH) with neointimal changes in adult rats. Although classic animal models of pulmonary hypertension (that is, the monocrotaline and hypoxic models) do not form obstructive intimal lesions in the peripheral pulmonary arteries, the SU5416 model has shown pulmonary arterial changes resembling plexiform lesions. Therefore, the SU5416 model of PAH has been used for some time, and it has thus contributed to a better understanding of the pulmonary hypertensive process. However, the mechanism by which SU5416 combined with chronic hypoxia can result in PAH with plexiform-like lesions in adult rats is complex and still remains to be fully elucidated. The most likely explanation is that there is in-
\end{abstract}

creased apoptosis of endothelial cells in response to the loss of the survival signaling, creating conditions favoring the emergence of apoptosis-resistant cells with increased growth potential, that is, the endothelial cell hyperproliferation that might characterize the plexiform lesions of human $\mathrm{PAH}$. The aim of the present review is to provide information useful for understanding a potent inhibitor of VEGF receptor tyrosine kinase, SU5416, and to better understand its use for generating animal models of PAH.

Copyright $\odot 2010$ S. Karger AG, Base

\section{Introduction}

Several lines of evidence indicate that vascular endothelial growth factor (VEGF), which is abundantly expressed in the normal lung [1], has a prosurvival and antiapoptotic role in endothelial cells (EC). SU5416, 3-(3,5-dimethyl-1H-pyrrol-2-ylmethylene)-1,3-dihydroindol-2-one, was the first VEGF receptor (VEGFR) 2 inhibitor to enter clinical development for cancer therapy. This compound is a selective and potent small molecule inhibitor of the VEGFR-2 tyrosine kinase. It has been shown to inhibit VEGF-dependent EC proliferation in vitro and in animal models [2, 3]. Moreover, SU5416 has shown broad in vivo antitumor activity [4].

\section{KARGER}

Fax +4161306 1234

E-Mail karger@karger.ch

www.karger.com (c) 2010 S. Karger AG, Basel

$0025-7931 / 11 / 0813-0253 \$ 38.00 / 0$

Accessible online at:

www.karger.com/res
Seiichiro Sakao, MD

Department of Respirology (B2), Graduate School of Medicine, Chiba University 1-8-1 Inohana, Chuo-ku

Chiba 260-8670 (Japan)

Tel. +81 43222 7171, ext. 5471, Fax +81 43226 2176, E-Mail sakaos@ faculty.chiba-u.jp 
After the essential role of angiogenesis was established in expansive cancer growth [5], antiangiogenic strategies directed at the developing tumor neovasculature, rather than the tumor cell, have been actively pursued. Phase I (dose escalation) studies showed that SU5416 was well tolerated at doses up to $145 \mathrm{mg} / \mathrm{m}^{2}$ (once or twice weekly) in patients with terminal cancers such as squamous carcinoma, angiosarcoma, colorectal and non-small cell lung cancer. Clinical benefit, such as tumor regression and disease stabilization, has been observed [6]. In a pilot phase I/II study, in which SU5416 was administered in combination with 5-fluorouracil and leucovorin to previously untreated patients with advanced colorectal cancer, no dose-limiting toxicity ascribed to SU5416 was seen. Furthermore, objective tumor responses were observed and median survival was found to exceed that for fluorouracil-leucovorin patients. These data suggest that SU5416 can improve the efficacy of standard fluorouracil-leucovorin therapy $[4,7]$. A randomized phase III trial of the same regimen, however, showed no statistically significant clinical benefit, although some individual patients showed striking responses [8]. As a result, further development of SU5416 was discontinued.

However, SU5416 has continued to be used in the laboratory. For example, Kasahara et al. [9] developed a rodent model of inflammation-independent emphysema based on the blockade of VEGF receptor signaling. This model provides an alternative explanation for emphysema based on the hypothesis that a failure of the lung cellular and molecular maintenance program may significantly contribute to the unique characteristics of pulmonary emphysema [9]. The evidence of lung airspace enlargement in newborn mice treated with a soluble VEGF receptor [10], and the reports of emphysema induced by EC immunization [11] or lung-specific deletion of VEGF using a Cre-Lox approach [12], all support the data obtained with this model [9]. The role of apoptosis in the lung destruction in emphysema is increasingly being recognized. Emphysema triggered by the VEGF receptor blocker SU5416, which is characterized by the presence of apoptotic alveolar septal cells, is prevented by a broad-spectrum caspase inhibitor [9]. Moreover, Tuder et al. [13] demonstrated that a superoxide dismutase mimetic protects against the development of apoptosis and emphysema induced by SU5416, thus suggesting that VEGF receptor blockade triggers lung oxidative stress, which is causally involved in alveolar septal cell death in this emphysema model.

A decade ago, Taraseviciene-Stewart et al. [14] showed that VEGF receptor blockade with the VEGFR-1/
VEGFR-2 antagonist SU5416 combined with chronic hypoxia resulted in severe angioproliferative pulmonary arterial hypertension (PAH) with neointimal changes in adult rats. Although classic animal models of pulmonary hypertension (that is, the monocrotaline and hypoxic models) do not form obstructive intimal lesions in the peripheral pulmonary arteries, the SU5416 model has shown pulmonary arterial changes resembling plexiform lesions. Moreover, a recent report clearly demonstrates that severe pulmonary hypertension in a very late stage of the SU5416/hypoxia/normoxia-exposed rat is accompanied by the formation of plexiform-like lesions that are indistinguishable from the pulmonary arteriopathy of human pulmonary arterial hypertension [15]. Therefore, the SU5416 model has been used for some time to study $\mathrm{PAH}$, thereby contributing to a better understanding of the pulmonary hypertensive process [16-20].

Although a number of studies have examined the mechanisms of action of the compound, it has not been conclusively demonstrated how SU5416 leads to the development of PAH in rats. This review seeks to explain how SU5416 works, why combining it with chronic hypoxia leads to PAH with plexiform-like lesions in adult rats and why the agent apparently specifically targets the lungs.

The aim of the present review is to provide information useful for understanding a potent inhibitor of VEGF receptor tyrosine kinase, SU5416.

\section{Vascular Endothelial Growth Factor}

VEGF is an obligatory survival factor for EC, since VEGF withdrawal from cultured EC induces apoptosis [21]. However, the overexpression of VEGF causes EC proliferation, formation of glomeruloid structures in the skin [22] or hypervascularization in the mouse trachea [23]. Withdrawal of VEGF or impaired signaling causes lung vessel loss as shown by Kasahara et al. [9] or more recently by Tang et al. [24]. It also causes capillary regression in skeletal muscle [25]. In contrast, the overexpression of VEGF is associated with tumor vessel growth [26] and EC proliferation in severe pulmonary hypertension [27]. Moreover, VEGF is critical for lung development and it also plays multiple physiological roles in the lung, including the regulation of vascular permeability. Increasing evidence in the current medical literature suggests that VEGF also plays a significant role in the development of several lung disorders, including lung cancer, chronic obstructive pulmonary disease, acute lung injury and PAH [28]. 
The biological activity of VEGF is dependent on its reaction with specific receptors. Three different receptors have been identified that belong to the tyrosine-kinase receptor family: VEGFR-1/Flt-1, VEGFR-2/Flk-1 (KDR), and VEGFR-3 (Flt-4). Both VEGFR-1 and VEGFR-2 have extracellular immunoglobulin-like domains as well as a single tyrosine kinase transmembrane domain and are expressed in a variety of cells [29]. Knockout of the genes encoding VEGF, VEGFR-1 and VEGFR-2 is embryonic lethal [30].

VEGF gene expression is known to be regulated by several factors, including hypoxia, growth factors, cytokines and other extracellular molecules [31]. Hypoxia plays a key role in VEGF gene expression both in vivo and in vitro, while VEGF mRNA expression is induced after exposure to low oxygen tension [32]. Hypoxia-induced transcription of VEGF mRNA is apparently mediated by the binding of hypoxia-inducible factor- 1 to a hypoxiainducible factor-1-binding site located in the VEGF promoter [31]. The human VEGF gene contains two hypoxiasensitive enhancer elements and several consensus-binding sites for growth factor-regulated transcription factors [33]. The presence of these regulatory sequences suggests the synergistic effect of both hypoxia and growth factors at the transcriptional level [33]. Growth factors that can stimulate VEGF production include epidermal growth factor, transforming growth factor- $\beta$ (TGF- $\beta$ ), keratinocyte growth factor and insulin-like growth factor $[31,34]$. These observations suggest that the paracrine or autocrine release of such factors cooperates with local hypoxia in regulating VEGF release in the microenvironment [34].

\section{VEGF Receptor Blockade with SU5416}

SU5416 can be classified as a high-clearance compound. Its intravenous pharmacokinetics are characterized by rapid elimination of the parent compound from the circulation. SU5416 has a short (approx. $30 \mathrm{~min}$ ) plasma half-life. Renal excretion of the compound is low, thus indicating that the primary route of elimination is via the hepatic metabolism [35].

Whole-body autoradiography was conducted in male rats using SU5416 labeled with $\left[{ }^{14} \mathrm{C}\right]$ in the benzene ring of the indolinone (a site considered to be most chemically and metabolically stable). Rats received a single intravenous dose of $\left[{ }^{14} \mathrm{C}\right]-S U 5416(5 \mathrm{mg} / \mathrm{kg} ; 43 \mathrm{lCi} / \mathrm{kg})$ and were sacrificed at $0.75,4$ and $24 \mathrm{~h}$. A wide distribution of radioactivity was observed at the 0.75 -hour time point, with the highest levels of total radioactivity present in the small intestinal contents and urine. The liver, kidney, skin, testes, brown fat, harderian gland and nasal turbinates also contained high levels of the compound. By $4 \mathrm{~h}$, a significant fraction of the total radioactivity was eliminated, with relatively high levels still noted in the small intestinal contents, cecum, urine, liver and kidneys. At $24 \mathrm{~h},>90 \%$ of the radioactive dose had been cleared, with the remainder concentrated in the gastrointestinal tract, liver and kidneys. These results indicated that SU5416 and its metabolites were readily cleared from the body and did not accumulate in major organs and tissues, and that there was no accumulation in the lung [36].

The predominant metabolite was identified as the primary alcohol SU9838, resulting from oxidation of the 5 -methyl group on the pyrrol ring of SU5416. SU9838 was further metabolized to its carboxylic acid, SU6595. Both SU9838 and SU6595 were further conjugated with glucuronic acid [37].

The importance of the rapid clearance of SU5416 to the development of severe angioproliferative $\mathrm{PAH}$ in rats was indicated by preclinical experiments using human EC in an in vitro proliferation assay, which demonstrated that a short exposure $(3 \mathrm{~h})$ to $5 \mu \mathrm{M}$ SU5416 resulted in inhibition of VEGF-dependent EC proliferation lasting at least $72 \mathrm{~h}[3,38]$. This suggests that high systemic exposure to SU5416 for a short period of time is sufficient to confer a durable effect in vivo. Despite its short plasma half-life (approx. $30 \mathrm{~min}$ ) [2], this effect was confirmed in three different human tumor xenograft models in mice when the agent was administered infrequently (once or twice a week). Human clinical study results also demonstrated biological activity when the patients received once or twice weekly intravenous infusion [6]. Once weekly dosing maintains a relatively high systemic exposure for a given dose of SU5416, as it prevents the induction of clearance seen with twice weekly infusions [6]. These results suggested that SU5416 has long-lasting inhibitory activity both in vivo and in vitro. To determine the basis for the prolonged activity of SU5416, cellular uptake assays using $\left[{ }^{14} \mathrm{C}\right]$-SU5416 were performed. It was found that SU5416 is preferentially concentrated in EC, and that these cells maintain an inhibitory concentration of SU5416 for a prolonged period even when the compound is no longer present in the medium [38]. A possible explanation for the ability of cells to concentrate SU5416 from the extracellular medium may be the hydrophobic nature of the compound, as indicated by its $\log \mathrm{D}$ value of $>5$. Therefore, the compound might be sequestered in the lipid membranes of the cell. Consistent with this hypoth- 
esis, preliminary cell fractionation experiments using HUVEC suggested that SU5416 is concentrated in the membrane fraction of the cells. From a reservoir in the cell membranes, the compound could partition into the cytosolic fraction of the cell so as to maintain inhibitory concentrations in the local environment of the membrane-associated Flk-1/KDR receptor kinase [38]. It should be noted that the long-term inhibitory activity of SU5416 is specific to the physicochemical properties of this compound; closely related, less hydrophobic compounds such as SU6668 do not demonstrate either longlasting activity or cellular concentrations in similar studies [39].

\section{The SU5416 Model and Classical Rodent Models of PAH}

Tuder et al. [40] demonstrated immunohistochemically and via in situ hybridization that the EC in the plexiform lesions, not in the normal vasculature, express mRNA and protein for VEGF (the survival factor for EC) and VEGFR-2, thus suggesting that the formation of these lesions in PAH involves a process of disordered angiogenesis. Moreover, in PAH, the population of lung EC expands in a monoclonal pattern [41], and these EC contain an inactivating mutation of the transforming growth factor receptor II [42]. Therefore, Taraseviciene-Stewart et al. [14] postulated that the occlusive neointimal lesions arise from a process of dysregulated angiogenesis that has several features in common with that seen in neoplastic processes. They used SU5416 to treat the rodent model of mild to moderate pulmonary hypertension under the chronic hypoxia. The results unexpectedly showed that in chronically hypoxic rats, SU5416 causes pulmonary arterial EC death, followed by obliteration of the precapillary arterial lumen by the proliferating EC, which is associated with a severe, irreversible PAH [14]. Moreover, the effect of the VEGF receptor blockade could be reversed by inhibitors of apoptosis, thus suggesting that increased apoptosis of EC in response to the loss of survival signaling creates conditions favoring the emergence of apoptosis-resistant cells with increased growth potential. Importantly, in this model, it was shown that chronic hypoxia plus VEGF receptor blockade caused severe pulmonary hypertension, which persisted, and even progressed, after the animals were no longer being subjected to the hypoxic stimulus. Moreover, the defining pulmonary vascular alteration, arterial occlusion by proliferating EC, was not reversible upon re-exposure to normoxia and with the passage of time after SU5416 injection (fig. 1) [14].

This model of severe PAH was therefore considered to be useful for better addressing the etiological mechanisms involved in the hyperproliferation of EC that characterizes the plexiform lesions of human PAH $[14,15]$. In contrast to this model, both classical rodent models of mild to moderate pulmonary hypertension - the chronic hypoxia and monocrotaline models - lack clustered proliferating EC in the lumen of the pulmonary arteries (fig. 1) [43, 44].

Pulmonary EC constitute a stable cell population with a very low turnover rate and, apparently, neither severe chronic hypoxia/hypoxemia nor monocrotaline pyrrole causes the emergence of a proliferative, dysfunctional EC phenotype [45]. The defining pulmonary vascular alteration in both of these models, medial muscular thickening of the proliferating SMC, is potentially reversible upon re-exposure to normoxia or with the passage of time after monocrotaline injection [43, 46, 47]. Taken together, these rat models offer the perspective that medial muscular thickening due to proliferating SMC may be reversible, while arterial occlusion by proliferating EC appears to be irreversible [48].

As mentioned above, irreversible arterial remodeling in the SU5416 model might explain the persistence and progression of pulmonary vascular disease and right heart failure with death of some, but not all, animals. The precise mechanisms involved in the hyperproliferation of EC induced by a VEGF receptor inhibitor is discussed more thoroughly below.

\section{SU5416 and Hyperproliferation of EC}

As mentioned above, the PAH model generated with SU5416 suggests that increased apoptosis of EC in response to loss of the survival signaling creates conditions favoring the emergence of apoptosis-resistant cells with increased growth potential [14]. Moreover, Campbell et al. [49] and Zhao et al. [50] demonstrated the overexpression of EC growth and survival factors, such as VEGF and angiopoietin-1, to prevent the development of monocrotaline-induced $\mathrm{PAH}$, an effect that was associated with reduced EC apoptosis. Together, these findings suggest that EC growth and the emergence of phenotypically altered vascular cells in severe PAH is the consequence of initial apoptosis and subsequent selection of apoptosisresistant, proliferative vascular cells. This concept is consistent with recent findings describing the absence of apoptotic cells in the plexiform lesions in the lungs from 
The monocrotaline and hypoxic models

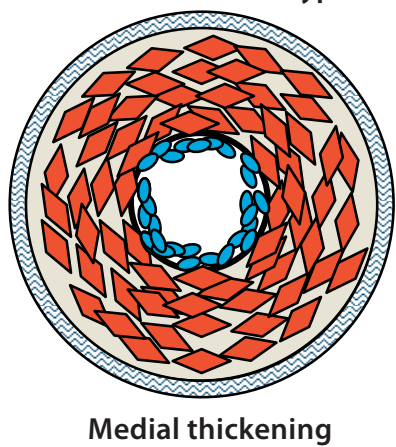

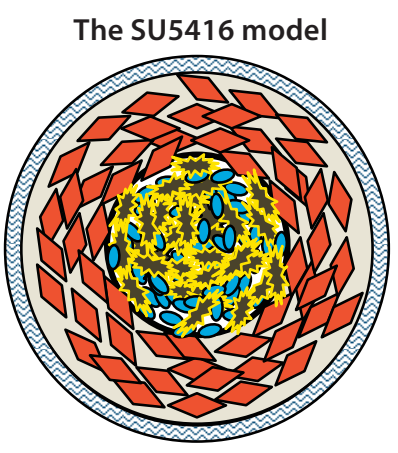

Neointimal occlusive lesions
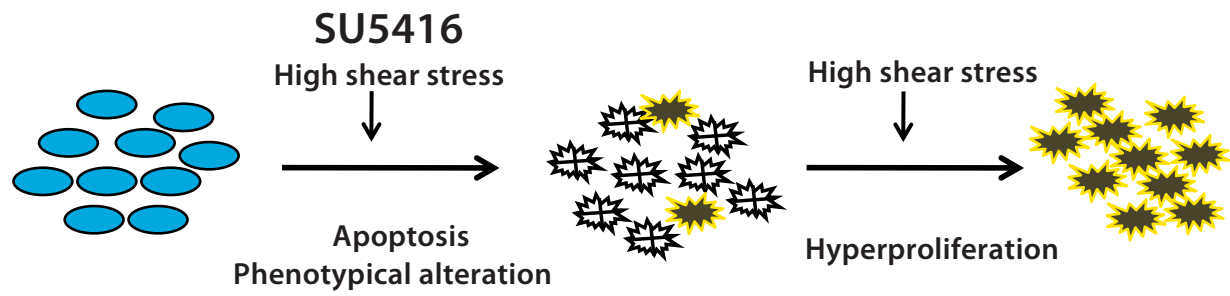

$E C$

SMC

Apoptotic cell

Apoptosis-resistant and phenotypically altered EC

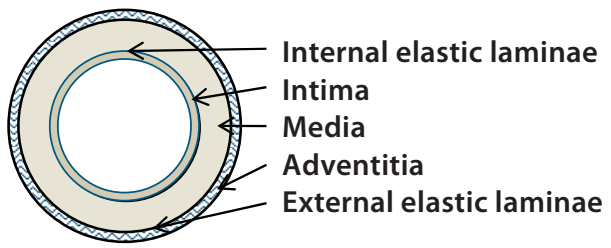

Fig. 1. Remodeling in the SU5416 model of pulmonary arterial hypertension. Although classic animal models of pulmonary hypertension (that is, the monocrotaline and hypoxic models) do not form obstructive intimal lesions in the peripheral pulmonary arteries, the SU5416 rats develop pulmonary arterial changes resembling plexiform-like lesions. Increased apoptosis of endothelial cells in response to the loss of survival signaling creates conditions favoring the emergence of apoptosis-resistant and phenotypically altered cells with an increased growth potential. This may allow for the endothelial cell hyperproliferation that characterizes the plexiform-like lesions of human PAH. SMC = Smooth muscle cells. patients with severe PAH [51], as well as the reduction of severe PAH in a rat model [14] following treatment with simvastatin, which induced apoptosis of the EC that had obliterated the pulmonary arterioles [52].

To study the dependence of EC hyperproliferation on initial apoptosis, we adapted the Cellmax artificial capillary system to analyze the effects of the VEGFR-1 and VEGFR-2 antagonist (SU5416) on human pulmonary microvascular EC (HPMVEC) under conditions of pulsatile shear stress [53]. The experiments with HPMVEC seeded in the artificial capillary system demonstrated that SU5416 induces EC apoptosis [53]. When this VEGF receptor blockade-induced apoptosis was followed by high fluid shear stress, a hyperproliferative state was generated, and within 7 days, phenotypically altered EC emerged
[53]. These altered EC expressed the tumor marker survivin and the antiapoptotic protein Bcl-XL, and were resistant to induction of apoptosis after challenge with TNF- $\alpha$ plus cycloheximide or hydrogen peroxide. In addition, the cells survived in a serum-free culture medium (fig. 1) [53].

It is unclear why the VEGFR blockade does not induce apoptosis in all of the EC, and whether the surviving cells are able to do so because they respond to survival signals which may be released by the dying cells. Because VEGFR inhibition allows apoptosis-resistant EC growth and because Partovian et al. [54] showed that adenovirus-mediated VEGF overexpression reduced pulmonary hypertension, it is not clear whether VEGF causes the angiogenic growth of the lumen-obliterating EC. It is possible 
that the overexpression of the VEGF and VEGFR-2 proteins in the human pulmonary vascular lesions is therefore a reflection of a vascular repair attempt.

The in vitro experimental model described above appears to support the concept that apoptosis-resistant hyperproliferative EC can emerge at shear stress-sensitive sites in the lungs during severe PAH. Although we did not experimentally address the factor or factors which confer apoptosis resistance and phenotypical alterations of a subpopulation of endothelial stem-like cells, we suggest that blockade of the signal transduction of the obligatory EC survival factor, VEGF, in combination with high shear stress provides a selection pressure. The nature of the surviving and proliferating cells remains unclear. It is possible, as stated above, that the surviving and proliferating cells are precursor cells $[55,56]$.

In vitro studies of HPMVEC have demonstrated SU5416 to suppress the PGI2S gene expression while potently inducing COX-2, VEGF and TGF- $\beta 1$ expression, thus causing the transdifferentiation of mature vascular EC (defined by Dil-Ac-LDL, lectin and factor VIII) into smooth muscle (SM)-like (as defined by expression of $\alpha$ SM actin) 'transitional' cells, which co-expressed both endothelial and SM markers [57]. In this experiment, the SU5416-induced transdifferentiation was independent of TGF- $\beta 1$ [57]. Although TGF- $\beta 1$ has been shown to be involved in inducing endothelial-mesenchymal transdifferentiation [58] and is known to promote SM actin expression in nonmuscle cells (EC and fibroblasts derived from various tissues) $[59,60]$, TGF- $\beta 1$ is currently thought to be insufficient to induce the expression of the late SM differentiation marker SM myosin heavy chain in nonSMC lineage cells [60]. SU5416 also expanded the number of CD34- and/or c-kit-positive cells and caused the transdifferentiation of CD34+ cells, but not CD34- cells.

In conclusion, these data showed that SU5416 generated a selection pressure that killed some EC and induced resident progenitor-like cells to transdifferentiate into SM-like cells [57]. Moreover, human pulmonary microvascular EC transdifferentiated with SU5416 in vitro suggest that endothelial-mesenchymal transdifferentiation might be an important contributor to pathophysiological vascular remodeling in the complex vascular lesions of PAH [57], because, although bone marrow-derived cells could participate in arterial neointimal formation after mechanical injury, they do not contribute substantially to pulmonary arterial remodeling in experimental $\mathrm{PAH}$ [61]. Moreover, those EC are not capable of returning to normal EC states over 10 passages from the withdrawal of SU5416 [57].

\section{Discussion and Conclusion}

Although classic animal models of pulmonary hypertension (that is, the monocrotaline and hypoxic models) do not form obstructive intimal lesions in the peripheral pulmonary arteries, the SU5416 rats develop pulmonary arterial changes resembling plexiform-like lesions [15, 48]. Increased apoptosis of EC in response to the loss of survival signaling creates conditions favoring the emergence of apoptosis-resistant and phenotypically altered cells with an increased growth potential [53]. This may allow for the EC hyperproliferation that characterizes the plexiform-like lesions of human PAH (fig. 1). However, a recent report clearly demonstrates that the plexiform lesions do not develop in this rat model of PAH until very late stages, and suggests that sustained exposure to very high blood pressure may be the major factor required for their development and that their development is independent of SU5416 injection/VEGFR blockade [15]. This indicates that the emergence of apoptosis-resistant and hyperproliferative EC by SU5416 may not be the direct factor required for their development and only induces the pulmonary arterial remodeling which results in exposure to high shear stress.

The SU5416 compound not only inhibits VEGFR-2 inhibitor, but also other tyrosine kinases, such as KIT, MET, FLT3 and RET. FLT3 and KIT with their ligands control the growth and differentiation of early human hemopoietic cells [62]. Indeed, SU5416 generated a selection pressure that killed some EC and expanded resident progenitor-like cells [57]. Therefore, the inhibition of these kinases could have relevance in this result. Moreover, other targets of SU5416 might have relevance in the pathomechanisms responsible for the development of the plexiformlike lesions seen in this model. This compound deserves further investigations.

As mentioned, SU5416 and its metabolites are readily cleared from the body and do not accumulate in any major organs or tissues, including the lungs. However, in rats, the combination of SU5416 and chronic hypoxia affected only the lung vasculature and not the vasculature of other organs [14]. One explanation for this lung-specific action might be that the lung EC, which are exposed to increased fluid shear stress because of chronic hypoxia and/or hypoxic vasoconstriction, are hyperproliferative because high fluid shear stress stimulates EC growth [51]. Therefore, VEGF is required for a vascular repair attempt in the pulmonary artery, but it is not required for merely maintaining mature vessels like systemic arteries [63], thus suggesting that they are particularly vulnerable to 
VEGFR-2 blockade. However, SU5416 could affect the normoxic pulmonary circulation because it increases pulmonary arterial pressure slightly but significantly under normoxic conditions [14]. Therefore, this explanation is not sufficient and further explanations are needed for this lung-specific action. Furthermore, pulmonary EC are exposed to the highest oxygen tensions in the body, which might further explain the response of these cells [14]. Moreover, pulmonary EC might maintain an inhibitory concentration of SU5416 for a prolonged period, even when the compound is no longer present in the cells of other organs. The precise reasons for all of these events, however, remain unknown.

This animal model of severe angioproliferative PAH with obstructive intimal lesions, like other models which recapitulate neointimal and plexiform lesions (that is, monocrotaline and pneumonectomy rats as well as the overexpression of S100A4/Mts1 in mice [64]), continues to be used and can therefore contribute to a better understanding of the pulmonary hypertensive process.

\section{Authors' Contributions}

S.S. conceived the report, contributed to its design and conception and drafted the manuscript. K.T. contributed to its design and drafted the manuscript. Both authors read and approved the final manuscript.

\section{Financial Disclosure and Conflicts of Interest}

This study was supported by research grants for the Respiratory Failure Research Group and the Cardiovascular Diseases (19-9, 22-33) from the Ministry of Health, Labor and Welfare, Japan, and a Grant-in-Aid for Scientific Research (Category C 22590851) from the Japanese Ministry of Education and Science. The authors declare that they have no competing interests.

\section{References}

1 Tuder RM, Flook BE, Voelkel NF: Increased gene expression for VEGF and the VEGF receptors KDR/Flk and Flt in lungs exposed to acute or to chronic hypoxia: modulation of gene expression by nitric oxide. J Clin Invest 1995;95:1798-1807.

2 Fong TAT, Shawver LK, Sun L, Tang C, App H, Powell TJ, Kim YH, Schreck R, Wang X, Risau W, Ullrich A, Hirth P, McMahon G: SU5416 is a potent and selective inhibitor of the vascular endothelial growth factor receptor (Flk-1/KDR) that inhibits tyrosine kinase catalysis, tumor vascularization, and growth of multiple tumor types. Cancer Res 1999;59:99-106.

- 3 Mendel DB, Laird AD, Smolich BD, Blake RA, Liang C, Hannah AL, Shaheen RM, Ellis LM, Weitman S, Shawver LK, Cherrington JM: Development of SU5416, a selective small molecule inhibitor of VEGF receptor tyrosine kinase activity, as an anti-angiogenesis agent. Anticancer Drug Design 2000;15: 29-41.

4 Rosen L, Mulay M, Mayers A, Kabbinavar F, Rosen P, Cropp G, Hannah A: Phase I doseescalating trial of SU5416, a novel angiogenesis inhibitor in patients with advanced malignancies. Proc Am Soc Clin Oncol 1999;18: 618.

5 Folkman J: Angiogenesis research: from laboratory to clinic. Forum 1999;9:59-62.
-6 Stopeck A, Sheldon M, Vahedian M, Cropp G, Gosalia R, Hannah A: Results of a phase I dose-escalating study of the antiangiogenic agent, SU5416, in patients with advanced malignancies. Clin Cancer Res 2002;8:2798 2805.

7 Miller LL, Elfring GL, Hannah AL, Allred R: Efficacy results of a phase I/II study of SU5416 (S)/5-fluorouracil (F)/leucovorin (L) relative to results in random subsets of similar patients (Pts) from a phase III study of irinotecan $(\mathrm{C}) / \mathrm{F} / \mathrm{L}$ or $\mathrm{F} / \mathrm{L}$ alone in the therapy of previously untreated metastatic colorectal cancer (MCRC). Proc Am Soc Clin Oncol 2001;20:144a.

-8 Shawver L, Slamon D, Ullrich A: Smart drugs: tyrosine kinase inhibitors in cancer therapy. Cancer Cell 2002;1:117-123.

-9 Kasahara Y, Tuder RM, Taraseviciene-Stewart L, Le Cras TD, Abman SH, Hirth P, Waltenberger J, Voelkel NF: Inhibition of vascular endothelial growth factor receptors causes lung cell apoptosis and emphysema. J Clin Invest 2000;106:1311-1319.

10 Gerber HP, Hillan HJ, Ryan AM, Kowalski J, Keller GA, Rangell L, Wright BD, Radtke F, Aguet M, Ferrara N: VEGF is required for growth and survival in neonatal mice. Development 1999;126:1149-1159.

11 Taraseviciene-Stewart L, Scerbavicius R, Choe KH, Moore M, Sullivan A, Nicolls MR, Fontenot AP, Tuder RM, Voelkel NF: An animal model of autoimmune emphysema. Am J Respir Crit Care Med 2005; 171:734-742.
12 Kang K, Wagner PD, Breen EC: Lung-specific inactivation of VEGF in adult mice leads to emphysema like changes. Am J Respir Crit Care Med 2002;165:B54.

13 Tuder RM, Zhen L, Cho CY, TarasevicieneStewart L, Kasahara Y, Salvemini D, Voelkel NF, Flores SC: Oxidative stress and apoptosis interact and cause emphysema due to vascular endothelial growth factor receptor blockade. Am J Respir Cell Mol Biol 2003;29:8897.

14 Taraseviciene-Stewart L, Kasahara Y, Alger L, Hirth P, Mc Mahon G, Waltenberger J, Voelkel NF, Tuder RM: Inhibition of the VEGF receptor 2 combined with chronic hypoxia causes cell death-dependent pulmonary EC proliferation and severe pulmonary hypertension. FASEB J 2001;15:427-438.

15 Abe K, Toba M, Alzoubi A, Ito M, Fagan KA, Cool CD, Voelkel NF, McMurtry IF, Oka M: Formation of plexiform lesions in experimental severe pulmonary arterial hypertension. Circulation 2010;121:2747-2754.

- 16 Kwapiszewska G, Wygrecka M, Marsh LM, Schmitt S, Trösser R, Wilhelm J, Helmus K, Eul B, Zakrzewicz A, Ghofrani HA, Schermuly RT, Bohle RM, Grimminger F, Seeger W, Eickelberg O, Fink L, Weissmann N: Fhl1 , a new key protein in pulmonary hypertension. Circulation 2008;118:1183-1194. 
17 Moreno-Vinasco L, Gomberg-Maitland M, Maitland ML, Desai AA, Singleton PA, Sammani S, Sam L, Liu Y, Husain AN, Lang RM, Ratain MJ, Lussier YA, Garcia JG: Genomic assessment of a multikinase inhibitor, sorafenib, in a rodent model of pulmonary hypertension. Physiol Genomics 2008;33: 278-291.

-18 Taraseviciene-Stewart L, Nicolls MR, Kraskauskas D, Scerbavicius R, Burns N, Cool C, Wood K, Parr JE, Boackle SA, Voelkel NF: Absence of T cells confers increased pulmonary arterial hypertension and vascular remodeling. Am J Respir Crit Care Med 2007; 175:1280-1289.

-19 Oka M, Homma N, Taraseviciene-Stewart L, Morris KG, Kraskauskas D, Burns N, Voelkel NF, McMurtry IF: Rho kinase-mediated vasoconstriction is important in severe occlusive pulmonary arterial hypertension in rats. Circ Res 2007;100:923-929.

-20 Taraseviciene-Stewart L, Gera L, Hirth P, Voelkel NF, Tuder RM, Stewart JM: A bradykinin antagonist and a caspase inhibitor prevent severe pulmonary hypertension in a rat model. Can J Physiol Pharmacol 2002;80: 269-274.

-21 Gerber HP, McMurtrey A, Kowalski J, Yan M, Keyt BA, Dixit V, Ferrara N: Vascular endothelial growth factor regulates EC survival through the phosphatidylinositol 3'kinase/Akt signal transduction pathway. Requirement for Flk-1/KDR activation. J Biol Chem 1998;273:30336-30343.

-22 Sundberg C, Nagy JA, Brown LF, Feng D, Eckelhoefer IA, Manseau EJ, Dvorak AM, Dvorak HF: Glomeruloid microvascular proliferation follows adenoviral vascular permeability factor/vascular endothelial growth factor-164 gene delivery. Am J Pathol 2001;158,1145-1160.

-23 Baluk P, Lee CG, Link H, Ator E, Haskell A, Elias JA, McDonald DM: Regulated angiogenesis and vascular regression in mice overexpressing vascular endothelial growth factor in airways. Am J Pathol 2004;165:10711085.

-24 Tang K, Rossiter HB, Wagner PD, Breen EC: Lung-targeted VEGF inactivation leads to an emphysema phenotype in mice. J Appl Physiol 2004;97:1559-1566.

-25 Tang K, Breen EC, Gerber H P, Ferrara NM, Wagner PD: Capillary regression in vascular endothelial growth factor-deficient skeletal muscle. Physiol Genomics 2004;18:63-69.

-26 Guo P, Xu L, Pan S, Brekken RA, Yang ST, Whitaker GB, Nagane M, Thorpe PE, Rosenbaum JS, Su Huang HJ, Cavenee WK, Cheng SY: Vascular endothelial growth factor isoforms display distinct activities in promoting tumor angiogenesis at different anatomic sites. Cancer Res 2001;61:8569-8577.

$\checkmark 27$ Tuder RM, Cool CD, Yeager M, Taraseviciene-Stewart L, Bull TM, Voelkel NF: The pathobiology of pulmonary hypertension. Endothelium. Clin Chest Med 2001;22:405418.
8 Voelkel NF, Vandivier RW, Tuder RM: Vascular endothelial growth factor in the lung. Am J Physiol Lung Cell Mol Physiol 2006; 290:L209-L221.

29 Mura M, dos Santos CC, Stewart D, Liu M: Vascular endothelial growth factor and related molecules in acute lung injury. J Appl Physiol 2004;97:1605-1617.

30 Carmeliet P, Ferreira V, Breier G, Pollefeyt S, Kieckens L, Gertsenstein M, Fahrig M, Vandenhoeck A, Harpal K, Eberhardt C, Declercq C, Pawling J, Moons L, Collen D, Risau W, Nagy A: Abnormal blood vessel development and lethality in embryos lacking a single VEGF allele. Nature 1996;380:435439.

31 Neufeld G, Cohen T, Gengrinovitch S, Poltorak Z: Vascular endothelial growth factor (VEGF) and its receptors. FASEB J 1999;13: $9-22$.

-32 Ferrara N: Molecular and biological properties of vascular endothelial growth factor. J Mol Med 1999;77:527-543.

33 Stavri GT, Zachary IC, Baskerville PA, Martin JF, Erusalimsky JD: Basic fibroblast growth factor upregulates the expression of vascular endothelial growth factor in vascular smooth muscle cells. Synergistic interaction with hypoxia. Circulation 1995;92:1114.

34 Ferrara N, Gerber HP, LeCouter J: The biology of VEGF and its receptors. Nat Med 2003;9:669-676.

-35 Sukbuntherng J, Cropp G, Hannah A, Wagner G, Shawver L, Antonian L: Pharmacokinetics and interspecies scaling of a novel VEGF receptor inhibitor, SU5416. J Pharm Pharmacol 2001;53:1629-1636.

-36 Ye C, Sweeny D, Sukbuntherng J, Zhang Q, Tan W, Wong S, Madan A, Ogilvie B, Parkinson A, Antonian L: Distribution, metabolism, and excretion of the anti-angiogenic compound SU5416. Toxicol In Vitro 2006; 20:154-162.

37 Antonian L, Zhang H, Yang C, Wagner G, Shawver L, Shet M, Ogilvie B, Madan A, Parkinson A: Biotransformation of the anti-angiogenic compound SU5416. Drug Metabol Disp 2000;28:1505-1512.

- 38 Mendel DB, Schreck RE, West DC, Li G, Strawn L.S, Tanciongco SS, Vasile S, Shawver LK, Cherrington JM: The angiogenesis inhibitor SU5416 has long lasting effects on VEGF receptor phosphorylation and function. Clin Cancer Res 2000;6:4848-4858.

39 Laird AD, Vajkoczy P, Shawver LK, Thurnher A, Liang C, Mohammadi M, Schlessinger J, Ullrich A, Hubbard SR, Blake RA, Fong TAT, Strawn LM, Sun L, Tang C, Hawtin R, Tang F, Shenoy N, Hirth KP, McMahn G, Cherrington JM: SU6668 is a potent anti-angiogenic and anti-tumor agent which induces regression of established tumors. Cancer Res 2001;60:4152-4160.

40 Tuder RM, Chacon M, Alger L, Wang J, Taraseviciene-Stewart L, Kasahara Y, Cool CD, Bishop AE, Geraci M, Semenza GL, Ya- coub M, Polak JM, Voelkel NF: Expression of angiogenesis-related molecules in plexiform lesions in severe pulmonary hypertension: evidence for a process of disordered angiogenesis. J Pathol 2001;195:367-374.

-41 Lee SD, Shroyer KR, Markham NE, Cool CD, Voelkel NF, Tuder RM: Monoclonal endothelial cell proliferation is present in primary but not secondary pulmonary hypertension. J Clin Invest 1998;101:927-934.

42 Yeager ME, Voelkel NF, Tuder RM: Mutational analysis of endothelial cell TGF-b receptor type II in plexiform lesions of patients with primary pulmonary hypertension. Circulation 1999;100:I-587.

$\checkmark 43$ Meyrick B, Reid L: Hypoxia-induced structural changes in the media and adventitia of the rat hilar pulmonary artery and their regression. Am J Pathol 1980;100:151-178.

44 Jones PL, Cowan KN, Rabinovitch M: Tenascin-C, proliferation and subendothelial fibronectin in progressive pulmonary vascular disease. Am J Pathol 1997;150:13491360.

45 Reid LM, Davies P: Control of cell proliferation in pulmonary hypertension; in Weir EK, Reeves JT (eds): Pulmonary Physiology and Pathophysiology. New York, Marcel Dekker, 1989.

46 Jeffery TK, Wanstall JC: Pulmonary vascular remodeling: a target for therapeutic intervention in pulmonary hypertension. Pharmacol Ther 2001;92:1-20.

47 Kakusaka I, Kaneko N, Kiyatake K, Fujita A, Suzuki A, Nakano K, Okada O, Sugita T, Watanabe S, Kuriyama T: Effects of various doses of monocrotaline administration on the development of pulmonary hypertension and its regression in rats. Nihon Kyobu Shikkan Gakkai Zasshi 1989;27:51-56.

48 Sakao S, Tatsumi K, Voelkel NF: Reversible or irreversible remodeling in pulmonary arterial hypertension. Am J Respir Cell Mol Biol 2009 Dec 11(e-pub ahead of print).

49 Campbell AI, Zhao Y, Sandhu R, Stewart DJ: Cell-based gene transfer of vascular endothelial growth factor attenuates monocrotaline-induced pulmonary hypertension. Circulation 2001;104:2242-2248.

50 Zhao YD, Campbell AI, Robb M, Ng D, Stewart DJ: Protective role of angiopoietin-1 in experimental pulmonary hypertension. Circ Res 2003;92:984-991.

51 Ameshima S, Golpon H, Cool CD, Chan D, Vandivier RW, Gardai SJ, Wick M, Nemenoff RA, Geraci MW, Voelkel NF: Peroxisome proliferatoractivated receptor $\gamma(\operatorname{PPAR} \gamma)$ expression is decreased in pulmonary hypertension and affects endothelial cell growth. Circ Res 2003;92:1162-1169.

52 Taraseviciene-Stewart L, Scerbavicius R, Choe KH, Cool C, Wood K, Tuder RM, Burns N, Kasper M, Voelkel NF: Simvastatin causes endothelial cell apoptosis and attenuates severe pulmonary hypertension. Am J Physiol Lung Cell Mol Physiol 2006; 291:L668-L676. 
53 Sakao S, Taraseviciene-Stewart L, Lee JD, Wood K, Cool CD, Voelkel NF: Initial apoptosis is followed by increased proliferation of apoptosis-resistant endothelial cells. FASEB J 2005;19:1178-1180.

54 Partovian C, Adnot S, Raffestin B, Louzier V, Levame M, Mavier IM, Lemarchand P, Eddahibi S: Adenovirus-mediated lung vascular endothelial growth factor overexpression protects against hypoxic pulmonary hypertension in rats. Am J Respir Cell Mol Biol 2000;23:762-771.

-55 Ingram DA, Mead LE, Tanaka H, Meade V, Fenoglio A, Mortell K, Pollok K, Ferkowicz MJ, Gilley D, Yoder MC: Identification of a novel hierarchy of endothelial progenitor cells using human peripheral and umbilical cord blood. Blood 2004;104:2752-2760.

56 Ingram DA, Mead LE, Moore DB, Woodard W, Fenoglio A, Yoder MC: Vessel wall derived endothelial cells rapidly proliferate because they contain a complete hierarchy of endothelial progenitor cells. Blood 2005; 105: 2783-2786.
57 Sakao S, Taraseviciene-Stewart L, Cool CD, Tada Y, Kasahara Y, Kurosu K, Tanabe N, Takiguchi Y, Tatsumi K, Kuriyama T, Voelkel NF: VEGF-R blockade causes endothelial cell apoptosis, expansion of surviving CD34+ precursor cells and transdifferentiation to smooth muscle-like and neuronallike cells. FASEB J 2007;21:3640-3652.

58 Frid MG, Kale VA, Stenmark KR: Mature vascular endothelium can give rise to smooth muscle cells via endothelial-mesenchymal transdifferentiation: in vitro analysis. Circ Res 2002;14:1189-1196.

59 Arciniegas E, Sutton AB, Allen TD, Schor AM: Transforming growth factor beta 1 promotes the differentiation of endothelial cells into smooth muscle-like cells in vitro. J Cell Sci 1992;103:521-529.

60 Hautmann MB, Adam PJ, Owens GK: Similarities and differences in smooth muscleactin induction by TGF- $\alpha$ in smooth muscle versus non-smooth muscle cells. Arterioscler Thromb Vasc Biol 1999;19:2049-2058.
1 Sahara M, Sata M, Morita T, Nakamura K, Hirata Y, Nagai R: Diverse contribution of bone marrow-derived cells to vascular remodeling associated with pulmonary arterial hypertension and arterial neointimal formation. Circulation 2007;115:509-517.

62 Yee KW, O'Farrell AM, Smolich BD, Cherrington JM, McMahon G, Wait CL, McGreevey LS, Griffith DJ, Heinrich MC: SU5416 and SU5614 inhibit kinase activity of wild type and mutant FLT3 receptor tyrosine kinase. Blood 2002;100:2941-2949.

63 Ellis LM, Liu W, Ahmad SA, Fan F, Jung YD, Shaheen RM, Reinmuth N: Overview of angiogenesis: biologic implications for antiangiogenic therapy. Semin Oncol 2001;28:94104

-64 Stenmark KR, Meyrick B, Galie N, Mooi WJ, McMurtry IF: Animal models of pulmonary arterial hypertension: the hope for etiological discovery and pharmacological cure. Am J Physiol Lung Cell Mol Physiol 2009; 297:L1013-L1032. 